\title{
Clinical Trial Investigator Meeting Material
}

National Cancer Institute

\section{Source}

National Cancer Institute. Clinical Trial Investigator Meeting Material. NCI Thesaurus.

Code C115599.

A collection of agendas, presentation materials, and other documents made available for attendees of a clinical trial investig ator meeting. 